\title{
Development of Student Islamic Behavior Through Worship Practice Activities at SMAN City of Bandung
}

\author{
Iha Hamidah, Agus Salim Mansyur, Supiana, Erihadiana \\ Sunan Gunung Djati State Islamic University, Bandung, Indonesia \\ Sunan Gunung Djati State Islamic University, Bandung, Indonesia \\ Sunan Gunung Djati State Islamic University, Bandung, Indonesia \\ Sunan Gunung Djati State Islamic University, Bandung, Indonesia \\ Email: ihahamidah@gmail.com, agussalimmansyur@uinsgd.ac.id,supiyana@uinsgd.ac.id, \\ erihadiana@uinsgd.ac.id
}

\begin{tabular}{|c|c|}
\hline ARTICLE INFO & ABSTRACT \\
\hline $\begin{array}{l}\text { Received } \\
23 \text { Juny } 2021 \\
\text { Revision } \\
1 \text { July } 2021 \\
\text { Approved } \\
10 \text { July } 2021 \\
\text { Keywords: } \\
\text { coaching } \\
\text { Islamic Behavior } \\
\text { Worship practice }\end{array}$ & $\begin{array}{l}\text { This study aims to describe the development of Islamic behavior of } \\
\text { students through the practice of worship at SMAN Bandung. Based on } \\
\text { observations and interviews of researchers to several principals of } \\
\text { SMAN schools in Bandung who have athlete students, found that not } \\
\text { all students who profess to be Muslim to perform worship well during } \\
\text { sports practice while in school, only some students who want to } \\
\text { perform worship in school, such as performing sunnah prayers or } \\
\text { obligatory prayers in school mosques, on the grounds that his clothes } \\
\text { are dirty because of sweat, responsibility is training and clashing with } \\
\text { training time. Whereas if praying his clothes must be clean and holy. } \\
\text { Sometimes, even many students have not prayed if they are not } \\
\text { ordered and many others lack. Not infrequently students who when at } \\
\text { home and at school show good Islamic behavior, but when outside the } \\
\text { house and outside the school shows bad behavior seen in terms of } \\
\text { Islam, such as smoking, hanging out on the side of the road, and } \\
\text { excessive dating. This study uses qualitative approach with descriptive } \\
\text { method. Data collection techniques through interviews, observations, } \\
\text { and documentation. Data analysis techniques use data analysis } \\
\text { techniques consisting of data reduction, data presentation, and } \\
\text { drawing conclusions. The results of this study are: } 1 \text { ) Islamic behavior } \\
\text { development program in high school in Bandung, namely } \\
\text { congregational prayers before the start and at the end of teaching and } \\
\text { learning activities, memorizing Asmaul Husna, reading the Quran } 15 \\
\text { minutes before the first hour. 1) learning begins, praying dhuha } \\
\text { congregation, praying midday congregation, infaq or setting aside } \\
\text { some pocket money for alms. 2) The process of fostering islamic keisk } \\
\text { behavior of students through religious practice activities in SMAN } \\
\text { throughout Bandung needs to be held, religious lectures, guidance } \\
\text { and supervision. } 3 \text { ) The behavior of students after receiving guidance } \\
\text { through the practice of worship in SMAN throughout The City of } \\
\text { Bandung is quite good. Students can be responsible and disciplined in } \\
\text { performing worship. Students can also work together and socialize } \\
\text { well. }\end{array}$ \\
\hline
\end{tabular}

How to cite:

E-ISSN: Published by:
Hamidah, Iha, Agus Salim Mansyur, Supiana, Erihadiana (2021) Development of Student Islamic Behavior Through Worship Practice Activities at SMAN City of Bandung. Jurnal of Social Science 2(4). https://doi.org/10.46799/jss.v2i4.183 2721-5202

Ridwan Institute 


\section{INTRODUCTION}

Recently, the phenomenon of moral decadence that occurs in society and in government circles is increasing and diverse. Crime, injustice, corruption, violence against children, human rights violations, are evidence that there has been a crisis of identity and character of the Indonesian nation. From these cases, it should be noted that deviations do not only occur in adults, but can occur among adolescents. The moral decline carried out by the youth of today is starting to worry.

According to Z. Daradjat, one of the moral crises that occurs in society is due to weak supervision so that the response to religion is lacking. The moral crisis indicates the quality of his religious education which should provide spiritual value but does not have the power because awareness in religion is lacking. All forms of irregularities that are often carried out by teenagers in schools are not in line with the existing National Education Goals (Daradjat, 2017).

In the law. 20 of 2003 Chapter 1 Article 1 concerning the National Education System explains that "Education is a conscious and planned effort to create a learning atmosphere and learning process so that students actively develop their potential, in order to have religious spiritual strength, selfcontrol, personality, intelligence, morals. noble character, as well as the skills needed by himself, society, nation and state.

Based on the law above, it is clearly illustrated that the purpose of national education has laid strong foundations in supporting the development of the character of the nation's identity. However, Muslim Affandi in his journal reveals that the development of the nation's character is now faced with various complex problems. The development of society is becoming increasingly dynamic as a result of globalization and the rapid advancement of communication and information technology. Thus, it requires maximum knowledge and sufficient skills (Muslim Afandi, Membangun Karakter Bangsa Melalui Pendidikan, 2013).

Coaching is a continuous effort or business activity to learn, improve, perfect, direct, develop the ability to achieve goals so that the target of coaching is able to live and practice Islamic teachings as a pattern of daily life that is good in personal, family, and social life. in society. Islamic behavior is a pattern of belief shown by a person in one's abilities, actions and habits both physically, spiritually, emotionally, and socially. Or Islamic behavior is all human behavior that reflects an attitude of obedience and obedience to God, which is manifested in terms of worship based on sincerity in order to get a reward.

In another sense, according to Ahyadi, what is meant by Islamic behavior or Islamic behavior is a statement or expression of human mental life that can be measured, calculated and studied which is manifested in the form of words, deeds or physical actions related to the experience of Islamic teachings. In the understanding of religious adherents to beliefs or teachings of God which of course is relative and of course the truth is also of relative value. Islamic behavior is behavior that is based on awareness about the existence of Islamic activities (Muhammad, 2008).

Islamic behavior is defined as the extent to which knowledge, belief, practice of worship and the rules and appreciation of the religion they adhere to. This Islamic behavior is shown by performing daily worship, praying, and reading the holy book). Islamic behavior is a person's belief in God, belief in the existence of God proves that a person has religious beliefs, is motivated to carry out religious orders, moral behavior according to religious guidance, and other Islamic activities aktifitas (Hafidhuddin, 2003).

Islam and education are two things that are related to each other. Through religion, humans are directed to become fully human in accordance with the values of Islamic teachings. The development process is through education. Because with education people will become more understanding and more capable both in terms of intelligence and mental attitude. Implementation of Islamic behavior development in schools requires deep interaction between teachers and students, both physically and mentally. Strengthening the quality of Islamic religious education deserves serious attention, considering that with Islamic religious education it is hoped that one's personality will become "insan kamil", a human who is useful for himself and his community and is happy and likes to practice and develop Islamic teachings in dealing with Allah and 
with others. fellow human beings, can take increasing benefits from this universe for the benefit of living in the world now and in the hereafter (Darajat Zakiya, 2004).

However, in reality, the development of Islamic behavior in schools is still considered to be less contributing to this direction. Weaknesses are still focused on the cognitive domain and still do not touch the affective and psychomotor domains. In fact, in order to achieve Islamic religious education, Islamic education must be able to touch the whole, both the cognitive, affective and psychomotor domains.

Islamic education is an effort to guide, direct and foster students which is carried out consciously and planned so that a main personality is developed in accordance with the values of Islamic teachings (Nata, 2004). In principle, religious education given in schools today plays an important role in building the personality, attitudes, ethics and behavior of teenagers among students in order to create a moral generation, with the aim of making students smart, skilled and of noble character. The development of Islamic behavior is a process of forming the Muslim personality in accordance with the instructions of Islamic teachings. Islamic teachings contain the attitudes and personal behavior of the community towards the welfare of individual and collective life, so Islamic education is individual education and community education.

The development of Islamic behavior as a process of developing obedient attitudes and behavior in carrying out the teachings of the religion they adhere to, being tolerant of the implementation of other worship and living in harmony with other religions gradually and regularly. The high and low level of a person's Islam can be known from his daily behavior. The higher the Islamic level, the higher the attitudes and behaviors that reflect a person's Islam. Conversely, the lower a person's Islamic level, the lower the attitudes and behaviors that reflect his Islamic attitude. Factors that influence the formation of Islamic attitudes include the efforts or efforts made by teachers in shaping students' Islamic attitudes, the influence of association with the environment, both the family environment and the environment outside the family, and The most influential are peers because children at this age are very easily influenced by the invitations of their friends.

Therefore, the teacher must make an earnest effort to shape the Islamic attitude of the student. The formation of an Islamic attitude must be formed as early as possible since the child is still in the educational stage. This is necessary so that they have a good Islamic attitude towards religion and Islamic rituals which are expected to become a habit in their later lives.

This study took three schools as samples, namely SMAN 20 Bandung with the address $\mathrm{Jl}$. Citarum no. 23 Bandung, West Java, Indonesia, while the second is at SMAN 25 Bandung with the address $\mathrm{Jl}$. Baturaden VIII No. 21, Mekarjaya, Kec. Rancasari, Bandung City, West Java 40292. While the third, namely SMA Negeri 10 Bandung which is located in East Bandung Jalan Cikutra Number 77 Telephone 022-727310, City of Bandung Prov. West Java. These three high schools are also used as model schools and reference schools in the city of Bandung because many students who become athletes have adequate infrastructure facilities as a place to develop their students, especially in the field of sports.

However, from the results of the preresearch through observations and interviews with several high school principals throughout the city of Bandung with athlete students, it was found the phenomenon that not all students who claim to be Muslims can carry out worship properly during sports training while at school, only Some students only want to carry out worship at school, such as performing sunnah prayers or compulsory prayers at the school mosque, on the grounds that their clothes are dirty with sweat, they are in the middle of training and clash with practice time. Meanwhile, when praying, the clothes must be clean and pure. In fact, sometimes many students do not pray if they are not ordered and there are many other shortcomings. It is not uncommon for students when at home or at school to show good Islamic behavior, but when outside the home or outside school they show behavior that is not good from an Islamic point of view, such as smoking, hanging out on the side of the road, and excessive dating (Interview). with Principal 10, 2019).

Winning in a match especially in the field of sports is very important, but there is 
something even more important, namely displaying the best skills while continuing to carry out Islamic behavior with passion. Sports education is a very powerful vehicle for breeding the behavior of the nation's children when systematically developed. Sport contains multi-dimensional dimensions of values and sportsmanship. First, sportsmanship, honesty, respect for friends and mutual support, helping and full of competitive spirit. Second, the attitude of cooperation, team work, mutual trust, sharing, interdependence, and decisionmaking skills. Third, the attitude and character that is always optimistic, enthusiastic, participatory, happy, and humorous. Fourth, creative individual development, full of initiative, leadership, determination, hard work, self-confidence, freedom of action, and self-satisfaction. The advantage of sports education in character building lies in the concretization of values into behavior which is a feature that is not easy to do with other substances in the curriculum and learning that tend to be theoretical, abstract, and verbalistic.

Character is closely related to behavior and values which can be defined as a consistent attitude to respond to situations through traits such as kindness, honesty, sportsmanship, responsibility, and respect for others but values are more important in the context of education, namely the formation of Islamic behavior and personality. The role of sport is increasingly important and strategic in the context of developing the quality of human resources who are healthy, independent, responsible, and have a high competitive nature.

Research on The Development of Islamic Behavior of Students Through The Activities of Worship Practice in SMAN Bandung Substantially this research is not the same as other research, and completely new. In this study will describe the improvement of Islamic behavior through the habituation of worship practices in athlete students at SMAN Bandung. The similarity of the above research is equally discussed about Islamic behavior. The objectives and subjects that will be studied in this study will further explain the development of Islamic behavior through the habituation of worship practices in athlete students in the city of SMAN Bandung, with pokus on the objectives, programs, processes, success rates, and evaluations.

\section{METHOD}

This study uses a qualitative approach. Qualitative approach is research that intends to understand the phonemena of what is experienced by the research subjects such as behavior perception, motivation, action and others holistically (intact), and by means of description in the form of words and language, in a special context that is natural and by utilizing various natural methods (Suharsimi Arikunto, 2006).

In this study, the method used was descriptive analytical research method. Bodgan and Taylor define the Descriptive Method of Analytics as a research procedure that generates data in the form of written or spoken words from people and observed behaviorsIn this study, the method used was descriptive analytical research method. Bodgan and Taylor define the Descriptive Method of Analytics as a research procedure that generates data in the form of written or spoken words from people and observed behaviors (Lexi J Moleong, 2008).

With this method, the data collected is in the form of words, images, and not numbers. In the writing of the report, researchers analyzed the very rich data as far as possible in their original from (Lexi J Moleong, 2008). Descriptive Analytical Method is a research that is intended to gather information about the status of an existing symptom, namely symptoms according to what it is, analyze, interpret, and conclude the data of research results on the formation of religious behavior through habituation of worship practices in athlete students in the city of Bandung on aspects of programs, processes, supporting and inhibitory factors, evaluation and success rate.

\section{RESULTS AND DISCUSSION}

\section{Islamic Behavior Development Program for Students Through Worship Practice Activities at Senior High Schools in Bandung}

The phenomenon of morality problems among students today is one of the educational problems that must get the attention of all parties. In accordance with Law no. 20/2003 concerning National 
Education System Article 1 paragraph (1) states that education is a conscious and planned effort to create a learning atmosphere and learning process so that students actively develop their potential to have religious spiritual strength, selfcontrol, personality, intelligence, noble character, as well as the skills needed by himself, society, nation and state (Muhaimin \& Pendidikan, 2006).

From the findings made through observations, interviews, and documentation of the Islamic Behavior Development Program for Students Through Worship Practice Activities at SMANs throughout the city of Bandung, especially in SMAN 20, SMAN 25 and SMAN 10 Bandung, it is realized in the form of several worship practices, as follows:

1) Pray together before starting and when teaching and learning activities are finished

The program of praying together before starting learning and when teaching and learning activities are finished every day is carried out in SMAN throughout the city of Bandung, especially at SMAN 20, Bandung City. Students pray together, guided by the teacher and guided by the class leader. Meanwhile, at SMAN 25 Bandung City, the implementation of joint prayer before starting teaching and learning activities was carried out after students carried out the breakfast menu. Because praying together is included in the breakfast menu list. The activity of praying together is guided by the teacher who teaches in the first hour. Meanwhile, at SMAN 10 Bandung, praying together led by class leader before starting the lesson. So basically these three schools have been praying both before and after learning, so it is a ceremonial event that has become a habit in the school, only the technicalities are different.

Praying etymologically means asking God, having goals that are not only heretical, but also worldly. Because prayer is not for the sake of God but for the benefit of man himself. Even if we pray to ask for everything we need, what we want or just to calm ourselves from all troubles, prayer has several benefits that are infinite. In the spiritual view, one will feel calm when side by side with his lover, and restlessness arises when left by him. The heart will be calm when we feel love for Allah, so try to present Allah in our hearts, surely our hearts will feel calm. In a hadith it is stated that Allah is always with you wherever you are. (HR Al-Thabrani) (Abdullah, 2005).

2) Memorizing Asmaul Husna

The worship practice program for memorizing Asmaul Husna has not been carried out routinely at SMAN 20 Bandung City, students usually only read Asmaul Husna every morning. As for SMAN 25, the implementation of memorizing Asmaul Husna is after the dhuha prayer in accordance with the breakfast menu of students who are guided by the teacher. While at SMAN 10 it is carried out before the dhuha prayer is carried out. So by memorizing Asmaul Husna students not only memorize the number and sequence of Asmaul Husna but also know meaning. In addition, students are guided to find out the meaning and significance of Asmaul Husna so that students can apply it in everyday life.

Ari Ginanjar Agustian puts forward the thought that every positive character will actually refer to the attributes of Allah contained in the 99 Asmaul Husna (good names of Allah) which numbered 99. This Asmaul Husna must be a source of inspiration for character formulation by anyone, because in Asmaul Husna contains the good qualities of Allah. According to Ari Ginanjar Agustian, of the many characters that can be imitated from the names of Allah, he summarizes them into seven basic characters, namely: Honesty, responsibility, discipline, cooperation, fairness, visionary, and caring (Agustian, 2009).

3) Read Al-Quran 15 Minutes Before The First Hour of Study Time Starts

The Al-Quran reading program before the first hour of learning begins at SMAN 20 Bandung City, namely after praying with students, they immediately read the Al-Quran 15 
minutes every morning before the learning process begins, guided by the teacher who teaches the first hour in each class. Meanwhile, at SMAN 25 Bandung, the practice or activity of reading the Koran 15 minutes before the first hour of learning begins is carried out every day with the hope that students are accustomed and fluent in reading the Koran. Reading the Quran is guided by the teacher. Meanwhile at SMAN 10 Bandung City Besides reading the Koran 15 minutes before the first hour of learning begins, there is also a schedule for reciting the Koran by reading it simultaneously all students are guided by the teacher who teaches in the first hour.

Al-Quran is the main reading for Muslims because Al-Quran is the main way of life. According to Quraish Shihab, the majesty and perfection of the Qur'an is not only known or felt by those who believe and expect its instructions, but also by all those who are intimately acquainted with the Qur'an (Shihab, 2018).

4) The Practice of Praying the Duha Prayer in Congregation

The congregational dhuha prayer program at SMAN 20 Bandung is that every day before break students are required to carry out two cycles of dhuha prayer in congregation. Students sometimes perform the Duha prayer alone and do not participate in congregation. The implementation of this dhuha prayer is guided by each class teacher. Meanwhile, at SMAN 25 Bandung, the congregational dhuha prayer is carried out two cycles every morning. Duha prayer is held in the school mosque in congregation. The implementation of the dhuha prayer is guided by the teacher, even before the teacher arrives the students are ready to perform the dhuha prayer without being ordered by the teacher.

Duha prayer is a generator of energy and a source of strength that will guide success (Shihab, 2018). Duha prayer is a vehicle to build spirituality on the sidelines of busy hours. That is, when we work hard to achieve success. This is where the dhuha prayer plays a role in creating a conducive atmosphere for the soul to always remember Allah.

5) Practice of Dzuhur Prayer in Congregation

The congregational Dzuhur prayer program is a sign of student obedience in carrying out their teachings. The implementation of the congregational midday prayer at SMAN 10 Bandung was attended by all students and all teachers and employees. The time is every day at $12.30-13.00$. As for the implementation of the congregational midday prayer at SMAN 25 Bandung City, it is held every day at 12.2513.00 . This activity was attended by all students from class X-XII also attended by all teachers and employees. After the congregational midday prayer, there is usually a religious lecture as a ceremonial event. While at SMAN 10, the congregational midday prayer is followed by all students and school residents regularly and programmed.

According to the science of Fiqh, prayer has a very important position that cannot be matched by any worship. Prayer is the pillar of religion, prayer is the practice of servants who are first judged on the Day of Judgment. Prayer is also the last item that disappears from religion, in the sense that if prayer is lost, then religion as a whole is lost (Shihab, 2018).

6) Infaq or set aside some pocket money for charity

The Infaq program or setting aside some pocket money for charity at SMAN 20 Bandung is held every Friday. Students give infaq money to their respective homeroom teachers. The goal is to train students to love charity and help others who are in trouble. Dapun at SMAN 25 Bandung City infaq or set aside some pocket money for charity is held every Friday. Apart from Friday students are prohibited from bringing pocket money. If a student is caught carrying pocket money other than Friday, the money will be included in infaq. The implementation of infaq for all students is given the task of collecting the money after everything 
has been collected and deposited by their respective homeroom teachers.

Giving alms teaches us that living in the world is not alone. So, we are educated to have a sense of caring, respect, and love for each other.

\section{The Process of Fostering Student's Islamic Behavior Through Worship Practice Activities at SMANs throughout the City of Bandung \\ The Process of Fostering Students'} Islamic Behavior Through Worship Practice Activities at SMANs throughout the City needs organizing, religious lectures, guidance and supervision. The explanation is as follows:

1) Organizing Student Islamic Behavior Development Through Worship Practice Activities

The school is an institution that has many people, consisting of the principal, teachers and personnel staff and students. These groups need to be empowered by combining all their potential so as to create good cooperation or create a conducive atmosphere in schools. The group collaboration needs to be well organized in order to achieve the desired goals effectively and efficiently. That's why the goal of the organization is to achieve goals together.

According to George R. Terry quoted by Mulyono, organizing is setting up effective behavioral relationships between personnel, so that they can work together efficiently and obtain personal decisions in carrying out tasks in existing environmental situations in order to achieve certain goals and objectives (Mulyono, Landasan pemikiran implementasi sistem manajemen mutu ISO 9001: 2008 di FITK UIN Malang, 2017).

Organizing the development of Islamic behavior of students through worship practices at SMAN 20 Bandung, which involves all school residents starting from the principal, coordinating religious activities, all teachers, homeroom teachers, and guardians of students. Everyone must work together so that the goals to be achieved can be realized. The organization of fostering Islamic behavior for students through worship practices at SMAN 25 Bandung City, which involves the Principal, ViceChancellor of Students, coordinator of worship development, coordinator of moral development, then homeroom teacher of each class and also guardian of students when students are at home. All of them work well together in carrying out the development of students' religious behavior through religious activities. Meanwhile, organizing the development of Islamic behavior of students through worship practices at SMAN 10 Bandung City, is carried out through one command starting from stakeholders, all Waka, IRMA coaches, teachers, walas and students who are also supported by parents. students to work together to make the program a success in order to achieve all goals.

Therefore, organization will determine the success of a program of activities such as religious development activities in schools. By organizing each individual has a duty and knows the authority and responsibility.

The explanation above shows the importance of organizing in religious activities in schools to ensure the continuity and success of the activities mandated to each individual.

2) Religious Lectures in Fostering Students' Islamic Behavior Through Worship Practice Activities

A lecture in the Indonesian dictionary is a speech that aims to provide advice and instructions while there is an audience who acts as a listener. The audience referred to here is all students in the madrasa or school and the teacher who guides.

Meanwhile, according to A. G. Lugandi, religious lectures are a unidirectional delivery of information, namely from the lecturer to the audience. (Lunandi, 1981). So what is meant by religious lectures is a method used by a preacher or muballigh in conveying a message to the audience and inviting the audience to the right path, in accordance with religious 
teachings in order to increase devotion to Allah SWT for the happiness of the world and the hereafter.

Religious lectures in fostering students' Islamic behavior through worship practices at SMAN 20 Bandung City are well-scheduled which are held every Thursday after the dhuha prayer in congregation. The implementation of religious lectures was followed by all students and guiding teachers. Religious lectures are more emphasized on religious material so that students' understanding of religion can increase and religious lectures can foster students' Islamic behavior and foster responsible, disciplined, and cooperative behavior.

The religious lectures in fostering students' Islamic behavior through religious activities carried out at SMAN 25 Bandung City, namely after the congregational midday prayer. The implementation of religious lectures has not been regularly scheduled at SMAN 25 Bandung City. Religious lectures are very important in their implementation in fostering Islamic behavior of students. So the teacher always gives advice to students at any time. Meanwhile, at SMAN 10 Bandung, it is scheduled and well organized through the IRMA coordinator every day after the midday congregational prayer performed by all school residents.

3) Guidance on Islamic Behavior Development through Worship Practices

The direction and guidance of teachers in fostering students' Islamic behavior through worship practices in schools will create a conducive school environment, a safe and comfortable learning atmosphere, not disturbed by attitudes that deviate from religious ethics and morals. The teacher's role is very influential on the formation of attitudes and personality, as well as the moral formation of students, because the teacher is an educator who is in the school environment whose function is to carry the mandate of parents in educating their children. Thus, in fostering the mental attitude and personality of the students, it cannot be separated from the role of the teacher at school.

Guidance for fostering student Islamic behavior through worship practices at SMAN 20 Bandung City is carried out by teachers together with parents and is supported by all school residents. The guidance process begins by giving advice so that good values are embedded in the students' souls. Then guide students to carry out religious activities well and provide examples or examples to students. The process of guiding students' Islamic behavior through worship practices at SMAN 25 Bandung City in the early stages before carrying out religious activities the teacher guides students to take ablution. After that the teacher gives advice so that students can be solemn and calm in carrying out religious activities. Then guide students to carry out worship practices well and provide examples or examples to students. While the process of guiding students' Islamic behavior through worship practices at SMAN 10 Bandung City is carried out through routine and programmed activities under the command of the IRMA supervisor at the school properly.

Thus the participation of all teachers is very influential on the development of students' religious morality. This can be done if the teacher realizes that he is not just teaching but educating so that when teaching any subject it is associated with religious value education. According to Ramayulis, the formation of a person's religious attitude can be done through 3 approaches, namely rational,emotional and exemplary approaches (Ramayulis, Psikologi Agama, 2007).

Thus teachers not only teach subject matter but also instill religious moral values to students. So they realize that their duty is not only to teach but also to educate children to have noble character. The teacher gives an understanding to students that the behavior of responsibility, discipline, and cooperation leads to 
noble character and is applied in everyday life.

4) Supervision of Islamic Behavior Development through Worship Practices

In carrying out the process of fostering students' Islamic behavior through worship practices, there must be supervision to control the implementation of worship practices carried out in SMANs throughout the city of Bandung, especially in SMAN 20, 25 and 10 in Bandung. In carrying out worship practices to foster student Islamic behavior, the aspect of supervision is a crucial factor. The result data shows that the coaching activities are in accordance with the target or not as measured by indicators of achievement and supervision from the Principal.

Supervision of the development of Islamic behavior of students through worship practices at SMAN 20 is carried out by the principal, homeroom teacher, and student guardian. Supervision carried out by the principal is to control the implementation of religious activities and supervise the guidance of teachers in carrying out religious activities. Teacher supervision when students are at school is by observing student behavior during the learning process and carrying out religious activities. In addition, the teacher also supervises through a connecting book that students must collect every day. Supervision of the development of student Islamic behavior is not only carried out at school but also must be supervised by parents at home.

The supervision of the development of students' religious behavior through worship practices at SMAN 25 is carried out by the principal, homeroom teacher, as well as all school residents and guardians of students. The principal always monitors all activities carried out in the madrasa. Apart from that, it also monitors teacher guidance in carrying out religious activities. Teacher supervision carried out at SMAN 25 is by observing student behavior when carrying out religious activities and during the learning process in class. In addition, the teacher also monitors student behavior through connecting books related to worship, social and independence that students must collect every day. Every Friday there is also a Friday prayer check list to control male students to be diligent in carrying out Friday prayers. In addition to the school that supervises the development of students' Islamic behavior, there must also be supervision from parents at home. While at SMAN 10 it is almost the same as at SMAN 25, only the difference is that at SMAN 10 it is more like Irma's supervisor as the person in charge of supervising the worship practices of her students at school and her parents at home.

The purpose of supervision is to help maintain results or outputs in accordance with system requirements. According to Nanang Fattah, several conditions must be considered in order for supervision to function effectively, including (Fattah, 2009):

a. Supervision must be carried out with objectives, and the criteria used in the education system are relevance, effectiveness, efficiency and productivity.

b. Achievable standards must be determined. There are two main objectives, namely: 1) to motivate, and 2) to be used as a benchmark to compare with achievement.

c. Supervision should be adapted to the nature and needs of the organization.

d. The amount of supervision should be limited.

e. The supervisory system must be steered without compromising managerial autonomy and respect but flexible, meaning that the control system indicates when, and where corrective action should be taken.

f. Supervision should refer to corrective action, which means not only revealing deviations from the standard, but providing alternative 
improvements,

determining

corrective actions.

g. Supervision should refer to problem solving procedures, countermeasures design, make repairs, check the results of repairs, prevent similar problems from occurring.

3. Islamic Behavior of Students After Getting Guidance Through Worship Practice Activities at Senior High Schools in Bandung.

The activity of fostering religious Islamic behavior carried out at SMAN 20, SMAN 25, and SMAN 10 Bandung City aims to foster students' religious behavior which includes responsible behavior, discipline, and cooperation. Behavior of responsibility and discipline here is more emphasized on the implementation of student worship while cooperation is emphasized on student behavior in socializing.

The development of worship practices has an important function in developing the character and personality of students. He also plays a role in the development of a healthy living system so that it can give birth to a generation that grows responsibly. Religious formation is a conscious effort to develop a way of life that follows religious orders. The lifestyle of religious adherents is based on the appreciation of the values they adhere to. Those values are absorbed to be practiced in everyday life.

The explanation of the Islamic behavior of students after receiving guidance on worship practices at SMAN 20, SMAN 25, and SMAN 10 Bandung City, is as follows:

1) Responsible Behavior

The behavior of students' responsibility in SMAN 20, SMAN 25, and SMAN 10 Bandung City in general is quite good. The responsible behavior of students at SMAN 20, Bandung City after receiving guidance on worship practices, namely students already have the responsibility to worship and obey the rules at school and at home even though there are still students who carry out religious activities or in learning by playing and disturbing her friend. The behavior of the responsibility of students at SMAN 25 Bandung in general is quite good. Students carry out worship properly and orderly. Meanwhile, the responsible behavior of SMAN 10 Bandung City students in general is quite good and in accordance with the school's vision and mission.

The responsible behavior of students in the three schools both at SMAN 20, SMAN 25, and SMAN 10 Bandung City is seen when students carry out religious activities at school and at home, do the tasks given by the teacher well, obey social rules that apply in the school environment and at home, as well as showing love and concern for the school environment.

2) Discipline Behavior

The application of good habits and discipline is the best educational factor and the most effective means to foster faith and noble character in children. This factor is best because it emphasizes the supervision and assistance of children, as well as using persuasion and threats, there is no doubt that the teaching and discipline given since childhood has always succeeded in bringing a child to success and happiness (Hurlock, 2009).

Discipline behavior of students at SMAN 20 Bandung City after receiving Islamic behavior coaching is quite good although sometimes there are students who are still lazy. The disciplinary behavior of students at SMAN 25 Bandung City has been formed in students after receiving guidance on worship practices. All school members are also very strict in supervising student discipline. Meanwhile, the disciplinary behavior of students at SMAN 10 Bandung City has been formed in students after getting guidance on worship practices and has become a daily habit for students either at school or at home.

Disciplinary behavior of students in SMAN in Bandung is seen when students obey the rules set together at school, carry out religious activities on time at the madrasa and at home, complete assignments from the teacher on time, and are consistent in carrying 
out worship practices both at school and at home.

The purpose of instilling discipline from an early age is to direct children so that they learn about good things which are preparation for adulthood. If discipline is instilled from an early age, they will make it a habit and part of themselves (Naim, 2012).

3) Cooperation Behavior

The cooperative behavior of students at SMAN 20 Bandung City after receiving guidance on worship practices is quite good. Students can socialize well. As for the cooperative behavior at SMAN 25 after getting Islamic behavior coaching, it's done quite good, even students have a social nature to help others who need help. Meanwhile, at SMAN 10 Bandung City, after receiving guidance on the practice of worship, it was quite good. This can be seen from the behavior and attitudes of students in carrying out worship practices in everyday life.

The cooperative behavior of students at SMANs throughout the city of Bandung is seen when students work together with teachers and friends in carrying out worship practices at school, work together in groups, and help fellow friends, help friends who experience calamities, and always behave well with teachers and peers.

According to Soerjono Soekanto, cooperation is a joint effort of individuals or groups to achieve certain goals. This opinion clearly states that cooperation is a form of relationship between several parties who interact with each other to achieve common goals (Soekanto, 2006).

Islamic behavior is the first and most important behavior that must be developed to children as early as possible, because of the religious teachings underpinning every life of individuals, communities and nations, especially in Indonesia because Indonesian society is a religious society. Man knows right and wrong is from his religious guidelines. Islamic behavior is not only related to the vertical relationship between man and his God but also concerns horizontal relationships between human beings. Islamic behavior is closely related to the religion it adheres to. While Islamic values are the values of life that reflect the growth of religious life consisting of three main elements, namely aqidah, worship, and morality.

\section{CONCLUSION}

Based on the above exposure, the The results of this study are: 1) The Islamic behavior development program in SMAN throughout the city of Bandung, namely praying together before starting and when teaching and learning activities are finished, memorizing Asmaul Husna, reading Al-Quran 15 minutes before the first hour of learning begins, praying dhuha together, pray dzuhur congregation, infaq or set aside some pocket money for charity. 2) The process of fostering students' Islamic behavior through religious practice activities at SMAN Se- Kota Bandung needs to be organized, religious lectures, guidance and supervision. 3) The Islamic behavior of students after receiving guidance through worship practices at SMANs throughout the city of Bandung is quite good. Students can be responsible and disciplined in carrying out worship. Students can also work together and socialize well.

\section{REFERENCES}

A. G. Lugandi. (2009). Pendidikan Orang Dewasa (Sebuah Uraian Praktek, Untuk Pembimbing, Penatar, Pelatih, dan Penyuluh Lapangan). Jakarta: Gramedia. Google Scholar

Abudin Nata. (2004). Metodologi Studi Islam . Jakarta: PT. Raja Grafindo. Google Scholar

Arismantoro. (2019). Tinjaun Berbagai Aspek Character Building. Cet. I. Jakarta:: Tiara Wacana.

Ary Ginanjar Agustian. (2009). ESQ (Emotional Spiritual Quontient). Jakarta: Arga Wijaya Persada. Google Scholar 
Didin Hafidhuddin. (2003). Islam Aplikatif. Jakarta: Gema Insani Press. Google Book

Elizabeth B Hurlock. (2009). Perkembangan Anak. Jakarta: PT Erlangga.

Lexi J Moleong. (2008). Metode Penelitian Kualitatif Edisi Revisi Cet. Ke-27. Bandung: Remaja Rosdakarya. Google Scholar

Maghfiroh. L. (2018). Strategi Peningkatan Mutu Pendidikan Madrasah Melalui Fotal Quality Management (TQM) Di Madrasah Ibtidaiyah Wahid Hasyim Yogyakarta. Jurnal Studi Pendidikan Islam V0I 1 No 1 Januari, 20. Google Scholar

Muhaimin. (2006). Nuansa Baru Pendidikan Islam. Jakarta: PT Raja Grafindo Persada. Google Scholar

Mulyono. (2017). Landasan Pemikiran Implementasi Sistem Manajemen Mutu Iso 9001: 2008 Di Fitk Uin Malang. JMpi (Jurnal Manajemen Pendidikan Islam), 61-68. Google Scholar

Mulyono. (2017). Manajemen Administrasi Dan Organisasi Pendidikan . Yogjakarta: Ar Ruzz Media.

Muslim Afandi. (2013). Membangun Karakter Bangsa Melalui Pendidikan. Jurnal Penelitian Dan Pendidikan Islam 6:, 366.

Muslim Afandi. (2013). Membangun Karakter Bangsa Melalui Pendidikan. Penelitian Dan Pendidikan Islam. Vol 6 No 2, 366.

Nanang Fattah. (2009). Landasan Manajemen Pendidikan. Bandung: PT Remaja Rosdakarya. Google Scholar

Nata, A. (1997). Filsafat Pendidikan Islam. Jakarta: Logos Wacana Ilmu. Google Scholar

Ngainun Naim. (2012). Character Building: Optimalisasi Peran Pendidikan Dalam Pengembangan Ilmu \& Pembentukan
Karakter Bangsa. Jogjakarta: Ar-Ruzz Media. Google Scholar

Quraish Shihab. (2018). Mukjizat Al-Quran. Bandung: Mizan.

Ramayulis. (2007). Psikologi Agama. Jakarta: Kalam Mulia.

Ramayulis. (2014). Ilmu Pendidikan Islam. Jakarta: Kalam Mulia.

Shobri. M. (2018). Strategi Meningkatkan Mutu Pendidikan Di Madrasah Aliyah Hasan Jufri Cendikia. Jurnal Studi Keislaman Vol 3 No 1 Juni P-Issn 24432741; E-Issn 2579-5503., 15. Google Scholar

Sholikin Muhammad. (2008). Filsafat dan Metafisika Dalam Islam, Sebuah Penjelajahan Nalar, Pengalaman Mistik, dan Perjalanan Aliran Manunggaling Kawula-Gusti. Jakarta: PT Buku Kita. Google Scolar

Soerjono Soekanto. (2006). Sosiologi Suatu Pengantar. Jakarta: Raja Grafindo Persada. Google Scholar

Suharsimi Arikunto. (2006). Prosedur Penelitian Suatu Pendekatan Praktik . Jakarta: Rineka Cipta. Google Scholar

Udik Abdullah. (2000). Meledakkan Iesq Dengan Langkah Taqwa Dan Tawakal. Jakarta: Zikrul Hakim. Google Scholar

Wawancara Dengan Kepala Sekolah 10, 2. 2. (2019, Mei 10).

Zakiah Darajat. (2010). Ilmu Pendidikan Islam Cet. 10. Jakarta: Bumi Aksara.

Zakiah Darajat,. (2004). Ilmu Pendidikan Islam. Jakarta: Bumi Aksara. Google Scholar 


\section{Copyright holder :}

Iha Hamidah, Agus Salim Mansyur, Supiana, Erihadiana (2021)

\section{First publication right :}

Journal of Social Science

This article is licensed under:

(c) (i) (2) 